\title{
XAVIER BICHAT
}

\section{AND THE MEDICAL THEORY \\ OF THE EIGHTEENTH \\ CENTURY}

by

\section{ELIZABETH HAIGH}

(Medical History, Supplement No. 4)

\section{LONDON \\ WELLCOME INSTITUTE FOR THE HISTORY OF MEDICINE 1984}




\section{CONTENTS}

Preface 1

Chapters

I The life of a young physician $\quad 2$

II Animism, vitalism, and the Medical University of Montpellier 15

III Irritability and sensibility: the forces of life 47

IV Medicine and ideology: the methodology and epistemology of the sensationalists $\quad 66$

$\begin{array}{lll}\text { V How to study life: Bichat's method } & 87\end{array}$

VI The forces of life and the causes of death $\quad 100$

$\begin{array}{ll}\text { VII The living elements } & 118\end{array}$

$\begin{array}{ll}\text { VIII After Bichat } & 132\end{array}$

$\begin{array}{ll}\text { Index } & 138\end{array}$ 


\section{XAVIER BICHAT AND THE MEDICAL THEORY OF THE EIGHTEENTH CENTURY}

(Medical History, Supplement No. 4) 
Published 1984 by the Wellcome Institute for the History of Medicine, 183 Euston Road, London NWI 2BP, England.

(C) Wellcome Institute for the History of Medicine, 1984.

\section{ISBN $085484046 \mathrm{X}$ ISSN 002572734}

Supplements to Medical History may be obtained at the Wellcome Institute, or by post from Science History Publications Ltd, Halfpenny Furze, Mill Lane, Chalfont St Giles, Bucks HP8 4NR, England.

WELLCOME TRUST CENTRE

FOR THE HISTORY OF MEDICINE ATV

24 EVERSHOLT STREET

LONDON

NWI IAD

UK

Printed by the Wellcome Foundation Limited, Print and Packaging Division (Crewe). 